Original Research Paper

\title{
Daya Ramban (Grazing) Ikan Baronang (Siganus guttatus) yang Dipelihara Dengan Rumput Laut Kappaphycus Alvarezii di Perairan Tanjung Tiram, Kabupaten Konawe Selatan
}

\author{
Rezki Amalyah ${ }^{1 *}$, Ma'ruf Kasim², Muhammad Idris ${ }^{3}$ \\ 1,2,3 Program Studi Ilmu Perikanan, Pasca Sarjana Universitas Halu Oleo, Kendari, Sulawesi Tenggara, Indonesia
}

Riwayat artikel

Received : 8 Maret 2019

Revised : 8 Juli 2019

Accepted : 21 Agustus 2019

Published : 30 Desember 2019

*Corresponding Author:

Rezki Amalyah,

Program Studi Ilmu Perikanan, Pasca Sarjana Universitas Halu Oleo, Kendari, Sulawesi

Tenggara, Indonesia

Email:

rezkiamalyah03@gmail.com
Abstrak: Serangan Hama dan penyakit merupakan penyebab terganggunya pertumbuhan rumput laut sehingga menyebabkan menurunnya produksi rumput laut. Salah satu hama dalam rumput laut adalah ikan baronang (Siganus guttatus). Tujuan dari penelitian ini adalah untuk mengetahui tingkat perambanan $S$. guttatus terhadap rumput laut $K$. alvarezii dengan kepadatan berbeda. Penelitian dilakukan pada bulan Januari 2018 di areal budidaya rumput laut perairan Desa Tanjung Tiram, Kabupaten Konawe Selatan. Penelitian dilakukan dengan menggunakan metode rakit jaring apung sebanyak 3 buah dengan ukuran $440 \times 100 \times 50 \mathrm{~cm}$. Rakit dibagi menjadi empat petak serta diberi label. Dalam masing-masing petak dibudidayakan rumput laut $K$. alvarezii dengan berat awal $100 \mathrm{~g}$ per rumpun dimana masing-masing unit percobaan dibedakan berdasarkan padat tebar $600 \mathrm{~g} / \mathrm{m}^{2}, 900 \mathrm{~g} / \mathrm{m}^{2}$ dan 1200 $\mathrm{g} / \mathrm{m}^{2}$. Pada setiap pengambilan data grazing (daya ramban) ikan baronang dalam wadah rakit apung ditebar 1 ekor ikan baronang dengan bobot sama sebesar $135 \mathrm{~g}$. Selama 21 hari penelitian, grazing ikan baronang tertinggi berada pada kepadatan $1200 \mathrm{~g} / \mathrm{m}^{2}$ sebesar $-23,58 \%$ dan yang terendah pada kepadatan $600 \mathrm{~g} / \mathrm{m}^{2}$ sebesar $-12,4 \%$.

Kata Kunci : Grazing, Ikan Baronang, Rumput laut, Rakit Jaring Apung

Abstract: Pest and disease attacks are a cause of disruption of seaweed growth, which causes a decrease in seaweed production. One pest in seaweed is baronang fish (Siganus guttatus). The aim of this study is to determine grazing rate of $S$. guttatus on $K$. alvarezii seaweed with different densities. The study was conducted in January 2018 in the area of seaweed cultivation in the waters of Tanjung Tiram village, South Konawe Regency. The total of plots in one unit of floating cage was three plots pieces measuring 440 x 100 x $50 \mathrm{~cm}$. Raft is divided into four plots and labeled. In each plot cultivated $K$. alvarezii seaweed with an initial weight of $100 \mathrm{~g}$ per clump where each experimental unit is differentiated based on stocking density of $600 \mathrm{~g} / \mathrm{m} 2,900 \mathrm{~g} / \mathrm{m} 2$ and $1200 \mathrm{~g} / \mathrm{m} 2$. At each grazing data collection (drilling power) Baronang fish in floating raft containers were stocked with one Baronang fish with the same weight of $135 \mathrm{~g}$. During maintenance, Baronang fish is given commercial feed as much as $5 \%$ of body weight. As for the 21 days of research, the highest Baronang fish grazing is at a density of $1200 \mathrm{~g} / \mathrm{m} 2$ at $-23.58 \%$ and the lowest at a density of $600 \mathrm{~g} / \mathrm{m} 2$ at $-12.4 \%$.

Keywords: Grazing, Baronang fish, seaweed, floating cage 


\section{Pendahuluan}

Rumput laut merupakan alga laut yang hidup pada perairan yang dangkal (mendominasi lingkungan bentik). Rumput laut menjadi sumber makanan utama dan juga sebagai habitat untuk berbagai organisme laut (Ahmed and Taparhudee, 2005; Athithan, 2014). Hingga saat ini, rumput laut telah dibudidayakan dan telah berkembang di banyak Negara seperti Jepang, Cina, Korea, Taiwan, Filipina, Malaysia, Indonesia dan Thailand (Ask and Azanza, 2002; Onho, 2004; Kavale et al., 2016).

Rumput laut yang umumnya dibudidayakan adalah Kappaphycus alvarezii yang biasa disebut dengan Euchema cottoni. K. alvarezii merupakan rumput laut yang memiliki nilai ekonomis tinggi (high value commodity) yaitu sebagai penghasil karagenan yang bermanfaat untuk bahan baku untuk industry farmasi, kosmetik, makanan dan lain-lain (Mubarak et al., 1990; Nontji, 2002). Rumput laut jenis ini juga banyak dibudidayakan karena teknologi budidaya yang mudah, siklus produksi yang relatif, biaya produksi relatif murah (Indriani dan Sumiarsih, 2003).

Keberhasilan budidaya dan kualitas rumput laut $K$. alvarezii yang dihasilkan tergantung pada cara perawatan dan pengendalian hama penyakit. Serangan hama dan penyakit dapat menyebabkan menurunnya produksi budidaya rumput laut. Umumnya serangan hama dilakukan oleh organisme laut yang mempunyai makananan utama atau sebagian masa hidupnya memangsa rumput laut. Secara fisik serangan hama dapat menyebabkan kerusakan pada tanaman budidaya seperti terkelupas, patah, bahkan habis dimakan. Aktifitas pemangsaan oleh organisme herbivora dapat menurunkan total produksi rumput laut hingga mencapai 60\% (Kasim dan Asnani, 2012).

Salah satu hama pada rumput laut adalah ikan baronang (Siganus guttatus). Eklof et al., (2006) menyatakan bahwa pada lokasi budidaya rumput laut banyak ditemukan ikan pemangsa rumput laut. Namun, yang paling banyak tertangkap adalah ikan baronang. Pola ini dikaitkan dengan keberadaan vegetasi, menunjukkan bahwa rumput laut mungkin sebagai tempat tinggal dan atau makanan bagi ikan.

Ikan baronang ( $S$. guttatus) termasuk dalam family Siganidae, merupakan ikan demersal yang hidup di dasar atau dekat dengan dasar perairan. Ikan ini banyak ditemukan di daerah padang lamun dan terumbu karang (Syafrudin, 2008). Ishak (2001) menyatakan bahwa Siganidae merupakan ikan herbivora. Ikan baronang $(S$. guttatus) sesuai dengan morfologis dari gigi dan saluran pencernaannya yaitu ukuran mulut yang kecil, dinding lambung agak tebal, usus halus panjang dan mempunyai permukaan yang luas sehingga ikan ini digolongkan sebagai ikan herbivora.

Ikan baronang ( $S$. guttatus) memakan rumput laut K.alvarezii dengan cara memotong ujung-ujung thallus dan menguliti thallus pangkal atau batang thallus sehingga yang tertinggal hanya kerangka thallus berwarna putih hal ini akan mengakibatkan rumput laut akan mudah terserang penyakit (Anggadireja et al., 2006). Mekanisme herbivori rumput laut oleh ikan baronang belum mendapat perhatian penuh dari para pembudidaya walaupun beberapa peneliti telah menyinggung masalah ini tetapi upaya untuk mengatasi hama dalam budidaya rumput laut berjalan lambat. Adapun teknik untuk mengatasinya seperti pemasangan jaring, berefisiensi rendah dan berbiaya mahal (Framegari et al., 2012).

Mengingat adanya serangan hama berupa ikan baronang (S. guttatus) yang mempengaruhi pertumbuhan dari rumput laut rumput laut $K$. alvarezii maka perlu diadakan penelitian tentang grazing (daya ramban) ikan baronang (S. guttatus) terhadap rumput laut (K. alvarezii) di Perairan Desa Tanjung Tiram. Hal ini sangat perlu dilakukan untuk menghadapi beberapa permasalahan yang dihadapi oleh petani rumput laut terhadap serangan ikan baronang (S. guttatus) yang mengganggu keberhasilan dalam pelaksanaan budidaya rumput laut. Penelitian ini bertujuan untuk mengetahui perambanan $S$. guttatus terhadap rumput laut $K$. alvarezii dengan kepadatan berbeda.

\section{Bahan dan Metode}

\section{a. Waktu dan Tempat}

Penelitian ini dilaksanakan selama 21 hari (Januari 2018) di areal budidaya rumput laut Perairan Tanjung Tiram, Kabupaten Konawe Selatan, Sulawesi Tenggara. Identifikasi si lambung ikan baronang dilakukan di Laboratorium Forensik Fakultas Matematika dan Ilmu Pengetahuan Alam (MIPA) Universitas Halu Oleo, Kendari.

Budidaya rumput laut di lokasi penelitian menggunakan metode rakit jaring apung. Rakit jaring apung yang digunakan sebanyak 3 buah. Kerangka rakit jaring apung terbuat dari pipa paralon 2,5 inchi dengan ukuran 440 × 100 × $50 \mathrm{~cm}$. Jaring berasal dari jaring multifilamen dengan mesh size $1 \mathrm{~cm}$. Rakit jaring apung dipetakan menjadi empat petak serta diberi label pada masing-masing sisi rakit jaring apung untuk memudahkan pada saat melakukan penelitian. Jenis rumput laut yang dibudidayakan adalah $K$. alvarezii dengan berat awal masing-masing rumput laut adalah sebesar $100 \mathrm{~g}$ per rumpun dimana masing-masing unit percobaan dibedakan berdasarkan padat tebar. Sedangkan ikan baronang ditebar sebanyak 7 ekor untuk tiap unit percobaan dengan bobot yang sama sebesar $35 \mathrm{~g}$. 


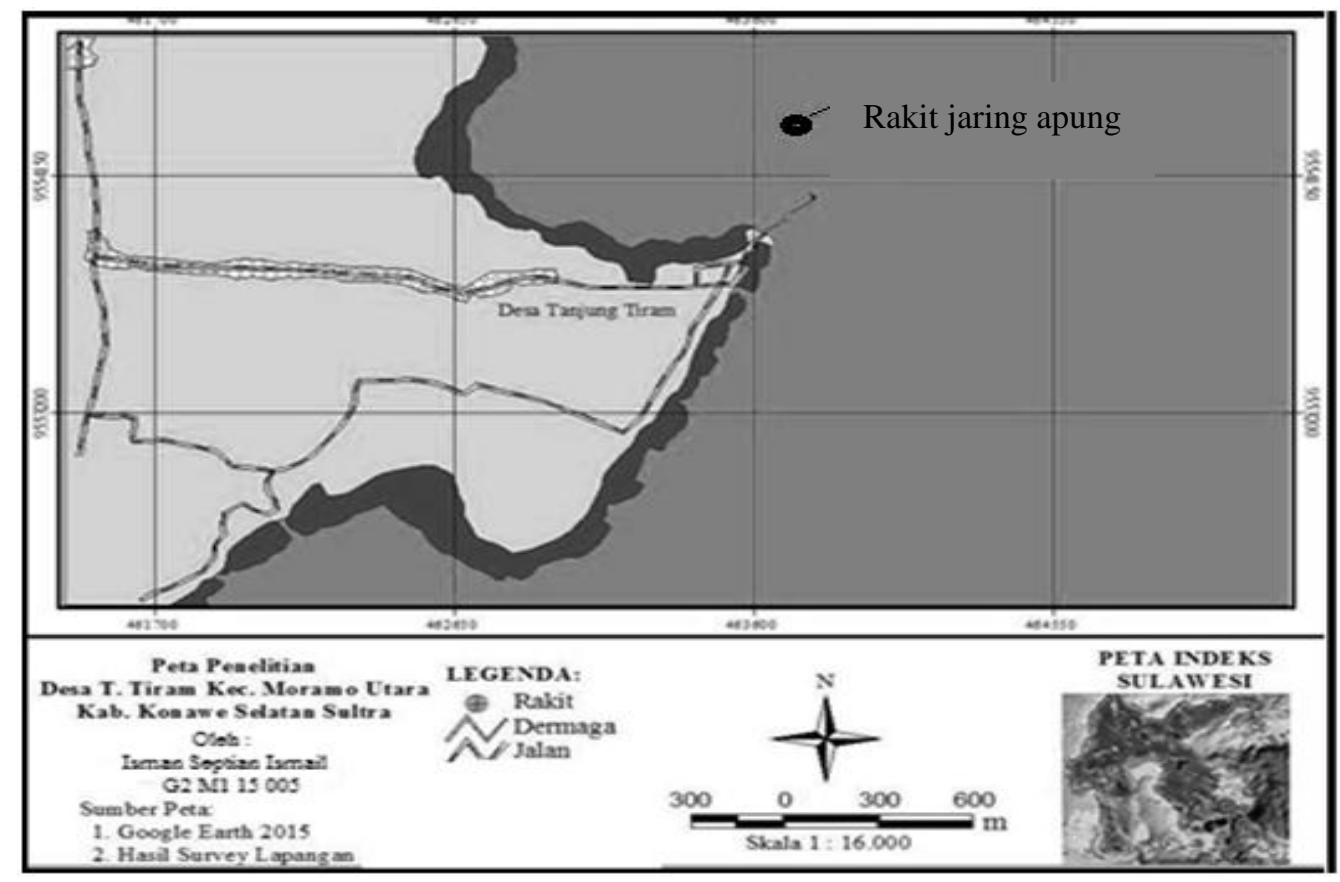

Gambar 1. Peta lokasi penelitian di Sungai Laeya

Ikan baronang yang telah didapatkan di alam terlebih dahulu diadaptasikan guna mengurangi tingkat stress setelah ditangkap dialam selama 3 hari. Ikan baronang yang dipilih adalah ikan yang sehat yang ditandai dengan gerakan yang lincah dan warna yang cerah serta tidak ada tanda-tanda kelainan fisik. Ikan yang dipilih ditimbang terlebih dahulu sebelum dilepas kedalam wadah rakit apung. Selama pemeliharaan, ikan baronang diberi pakan komersil sebanyak 5\% dari bobot tubuh.

Penelitian ini menggunakan Rancangan Acak Lengkap (RAL) dengan mengaplikasikan 3 perlakuan dengan 3 ulangan. Adapun penempatan satuan percobaan akan dilakukan secara acak. Tata letak wadah penelitian dapat dilihat pada gambar 2 berikut:

\begin{tabular}{|c|c|c|}
\hline $1(\mathrm{~A})$ & $5(\mathrm{C})$ & $9(\mathrm{C})$ \\
\hline $2(\mathrm{C})$ & $6(\mathrm{~B})$ & $10(\mathrm{~A})$ \\
\hline $3(\mathrm{~B})$ & $7(\mathrm{~A})$ & $11(\mathrm{~B})$ \\
\hline
\end{tabular}

Gambar 2. Tata letak wadah penelitian

Keterangan :

Perlakuan A : Padat tebar rumput laut $600 \mathrm{~g} / \mathrm{m}^{2}$

Perlakuan B : Padat tebar rumput laut $900 \mathrm{~g} / \mathrm{m}^{2}$

Perlakuan C : Padat tebar rumput laut 1200 $\mathrm{g} / \mathrm{m}^{2}$

Pengamatan sampel dilakukan setiap 3 hari sekali. Pengamatan dilakukan dengan mengambil rumpun rumput laut disetiap wadah kemudian ditimbang bobotnya. Selanjutnya dilakukan penimbangan bobot ikan baronang dan sampel ikan baronang dibawa ke laboratorium untuk dilakukan identifikasi isi lambungnya.

\section{b. Analisis Data}

\section{Pertumbuhan Ikan Baronang}

Pertumbuhan mutlak rumput laut dan ikan baronang, diamati dari awal hingga berakhirnya penelitian. Menurut Ahmad (2006), Pertumbuhan mutlak diukur dengan menggunakan rumus :

$$
\mathrm{G}=\mathrm{Wt}-\mathrm{W}
$$

Keterangan :

$\mathrm{G}=$ Pertumbuhan mutlak rata-rata $(\mathrm{g})$

$\mathrm{Wt}=$ Berat/bobot rata-rata pada akhir penelitian $(\mathrm{g})$

$\mathrm{Wo}=$ Berat/bobot rata-rata pada awal penelitian $(\mathrm{g})$

\section{Grazing (Daya Ramban)}

Persentase perubahan bobot $\mathrm{RL}=\frac{\mathrm{Wt}-\mathrm{W} 0}{\mathrm{~W} 0} \times 100$

Keterangan :

$\mathrm{RL}=$ Rumput Laut

$\mathrm{Wt}=$ Bobot rata-rata pada akhir penelitian $(\mathrm{g})$

$\mathrm{W} 0=$ Bobot rata-rata pada awal penelitian $(\mathrm{g})$

3. Pengaruh padat tebar rumput laut K. alvarezii terhadap grazing ikan baronang

Hubungan antara perlakuan (metode budidaya) terhadap grazing ikan baronang dilakukan dengan menggunakan metode analisis Correlate Bivariate 
Pearson yang dianalisis dengan bantuan perangkat lunak (software) SPSS versi 16,0.

4. Hubungan antara grazing ikan baronang dan pertumbuhan ikan baronang

Hubungan antara grazing ikan baronang terhadap pertumbuhan ikan baronang dilakukan dengan menggunakan metode analisis Correlate Bivariate Pearson yang dianalisis dengan bantuan perangkat lunak (software) SPSS versi 16,0.

\section{Hasil dan Pembahasan}

\section{Hasil}

1. Pertumbuhan Ikan Baronang

Pertumbuhan Ikan baronang selama 21 hari masa penelitian ditunjukkan pada Gambar 3.

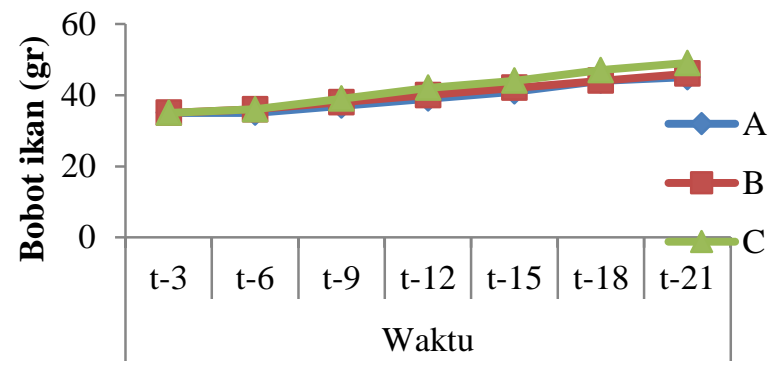

Gambar 3. Pertumbuhan Ikan Baronang selama 21 hari

2. Grazing ikan baronang terhadap rumput laut

Tabel 1. Grazing ikan baronang terhadap rumput laut

\begin{tabular}{|c|c|c|c|}
\hline Perlakuan & $\begin{array}{c}\text { Bobot } \\
\text { Awal (gr) }\end{array}$ & $\begin{array}{c}\text { Rata-rata Bobot } \\
\text { akhir (gr) }\end{array}$ & $\begin{array}{c}\text { Grazing } \\
(\%)\end{array}$ \\
\hline A & 600 & 458,5 & $-12,4$ \\
\hline B & 900 & 742,3 & $-17,52$ \\
\hline C & 1200 & 1051,2 & $-23,58$ \\
\hline
\end{tabular}

3. Analisis Isi lambung ikan baronang

Berdasarkan hasil pengamatan menggunakan mikroskop dengan mengamati isi lambung ikan baronang dan preparat bandingan dari rumput laut, ditemukan bahwa dominan isi lambung dari ikan baronang tersebut adalah rumput laut. (Gambar 4).
4. Hubungan antara perlakuan terhadap grazing ikan baronang

Tabel 2. Analisis Anova antara perlakuan terhadap grazing ikan baronang

\begin{tabular}{|l|c|c|c|c|c|}
\hline & $\begin{array}{c}\text { Sum of } \\
\text { Squares }\end{array}$ & Df & $\begin{array}{c}\text { Mean } \\
\text { Square }\end{array}$ & F & Sig. \\
\hline $\begin{array}{l}\text { Between } \\
\text { Groups }\end{array}$ & 681,141 & 2 & 340,570 &, 172 &, 843 \\
\hline $\begin{array}{l}\text { Within } \\
\text { Groups }\end{array}$ & 119067,796 & 60 & 1984,463 & & \\
\hline Total & 119748,937 & 62 & & & \\
\hline
\end{tabular}

5. Hubungan antara grazing ikan baronang terhadap pertumbuhan ikan baronang

Tabel 3. Analisis korelasi antara grazing ikan baronang terhadap pertumbuhan ikan baronang

\begin{tabular}{|l|l|r|r|}
\hline \multicolumn{2}{|c|}{} & Grazing & $\begin{array}{l}\text { Pertumbuhan } \\
\text { Ikan } \\
\text { Baronang }\end{array}$ \\
\hline \multirow{3}{*}{ Grazing } & Pearson Correlation & 1 &, $676^{* *}$ \\
\cline { 2 - 4 } & Sig. (2-tailed) & &, 001 \\
\cline { 2 - 4 } & $\mathrm{N}$ & 21 & 21 \\
\hline $\begin{array}{l}\text { Pertumbuhan } \\
\text { Ikan Baronang }\end{array}$ & Pearson Correlation &, $676^{* *}$ & 1 \\
\cline { 2 - 4 } & Sig. (2-tailed) & 001 & \\
\cline { 2 - 4 } & $\mathrm{N}$ & 21 & \\
\hline **. Correlation is significant at the 0.01 level (2-tailed). \\
\hline
\end{tabular}

\section{Pembahasan}

\section{Pertumbuhan Ikan Baronang}

Pendugaan Pertumbuhan ikan baronang di lokasi penelitian dipengaruhi oleh keberadaan rumput laut. Pertumbuhan ikan baronang selama periode penelitan tertinggi berada pada padat tebar rumput laut $1200 \mathrm{~g} / \mathrm{m}^{2}$ dan terendah pada padat tebar rumput laut $600 \mathrm{~g} / \mathrm{m}^{2}$ (Gambar 3). Pertumbuhan ikan baronang pada padat tebar $1200 \mathrm{~g} / \mathrm{m}^{2}$ lebih cepat bila dibandingkan dengan pertumbuhan ikan baronang pada padat tebar $600 \mathrm{~g} / \mathrm{m}^{2}$ dam $900 \mathrm{~g} / \mathrm{m}^{2}$. Hal tersebut dikarenakan kepadatan rumput laut yang lebih banyak. Hal tersebut sejalan dengan penelitian yang dilakukan oleh Faisal (2013) yang mengamati pertumbuhan rumput laut dan ikan baronang yang dibudidayakan bersama di keramba tancap dengan padat tebar rumput laut 9, 18 dan 27 rumpun dimana pertumbuhan ikan baronang tertinggi berada padat tebar 27 rumpun rumput laut.

Pertumbuhan ikan baronang tidak terlalu signifikan disebabkan karena sumber makanan hanya berasal dari dalam kurungan saja, sehingga ikan baronang tidak mendapatkan asupan makanan yang cukup dan harus berkompetisi dengan individu lainnya. Hal tersebut didukung oleh pernyataan Pillans (2004); Faisal et al., (2013) yang menyatakan bahwa faktor tumbuh ikan sangat dipengaruhi oleh ketersediaan 
makanan. Akan tetapi, meskipun ketersediaan makanan dalam kurungan terbatas, ikan baronang mendapatkan suplai makanan yang terbawa oleh arus ataupun lumut /alga yang menempel pada kurungan tersebut.

\section{Grazing Ikan Baronang terhadap rumput laut}

Kegiatan budidaya rumput laut merupakan suatu kegiatan yang menjanjikan dalam aspek perikanan. Hal tersebut bersinergi dengan taraf ekonomi pembudidaya yang cukup berkembang. Keberhasilan dalam budidaya rumput laut ditentukan oleh metode dan cara perlakukan. Bagi sebagian pembudidaya, metode dan cara perlakukan yang baik telah diaplikasikan dengan mantap dan telah dibuktikan oleh kebanyakan pembudidaya di berbagai daerah. Kondisi ini tentu menjadi pertimbangan dan skala prioritas bagi pembudidaya untuk tetap mengembangkan kegiatan tersebut. Namun sayangnya, keberhasilan dalam sistem budidaya rumput laut tidak selamanya dapat dirasakan oleh semua pembudidaya. Kegiatan budidaya ini sering menghadapi berbagai tantangan dan masalah, sehingga menjadi faktor utama yang dapat merugikan para pembudidaya.

Hal yang merugikan tersebut telah dirasakan oleh beberapa pembudidaya di wilayah perairan Tanjung Tiram. Salah satu masalah yang sering kali dihadapi para pembudidaya adalah kehadiran hama pengganggu. Hama pengganggu yang dimaksud disini adalah ikan baronang. Seperti yang telah kita ketahui bahwa ikan baronang memiliki tingkat grazing yang cukup tinggi kaitannya dalam sistem budidaya rumput laut. Hal tersebut telah dibuktikan melalui kegiatan penelitian ini.

Hasil penelitian menunjukkan bahwa telah terjadi penurunan bobot rumput laut pasca penimbangan akhir. Tiga perlakuan yang telah diuji yakni padat tebar rumput laut 600 gr, 900 gr, dan 1200 gr didapatkan penurunan bobot yang cukup signifikan yakni masing-masing 485,5 gr, 742, 3gr, dan 1051,2 gr. Besarnya bobot rumput laut yang dimakan oleh ikan baronang selama periode penelitian berkisar antara 140-150 gr. Tingkat persentase grazing ikan baronang dinilai merata pada tiga nilai bobot rumput laut yang diteliti. Hal ini bermakna bahwa pengaruh grazing ikan baronang terhadap rumput laut adalah berpengaruh signifikan. Hasil penelitian ini didukung oleh Framegari et al., (2012) yang menyatakan bahwa konsumsi ikan baronang terhadap rumput laut jenis $K$. alvarezii berpengaruh sangat nyata. Hasil penelitian ini sejalan dengan hasil penelitian Kasim dan Mustafa (2017) yang menyatakan bahwa ikan baronang lebih menyukai rumput laut sebagai makanan utamanya dibandingkan dengan makrofit lain seperti lamun. Hal tersebut juga diperkuat dengan hasil penelitian Faizal et al., (2013) yang menyatakan bahwa pada periode penelitiannya telah terjadi penyusutan bobot hingga 39,63gr dari bobot awalnya. Hal tersebut juga didukung oleh pernyataan Feng at el., (2003) yang menyatakan bahwa ikan baronang hanya akan memakan cabangcabang rumput laut jenis $K$. Alvarezii yang kecil atau yang masih muda.

\section{Analisis Isi Lambung Ikan Baronang}

Berdasarkan hasil pengamatan, jenis makanan yang ditemukan pada sistem pencernaan ikan baronang didominasi oleh jenis alga yang berarti ikan baronang jenis $S$. guttatus merupakan kelompok hewan herbivora. Hal tersebut didukung oleh pernyataan Mayunar (2005), yang menyatakan bahwa ikan herbivora merupakan golongan ikan yang memakan bahan tumbuhan yang hidup di air atau di dalam lumpur misalnya alga. Kebiasaan makan ini sesuai dengan morfologi gigi dan saluran pencernaan ikan baronang yaitu mulut yang berukuran kecil, usus halus panjang dan mempunyai permukaan yang luas. Secara umum, organisme ikan dengan morfologi demikian mempunyai makanan utama yaitu lamun, sedangkan makanan pelengkapnya yaitu alga dan crustacea. Hal tersebut didukung pula oleh pernyataan Merta (1982) yang menyatakan bahwa ditemukan jenis tumbuhan pada lambung ikan baronang yang sebagian besar adalah potongan-potongan rumput laut. Hal tersebut diketahui karena masih terlihat potongan ataupun ada beberapa yang ditemukan dalam kondisi utuh dan terihat jelas berbentuk seperti jel dengan warna hijau kecoklatan serta serat tumbuhan lainnya. Hal tersebut didukung pula oleh pernyataan Faisal et al., (2013) yang menyatakan bahwa rumput laut merupakan salah satu makanan paling disukai ikan baronang, bahkan ikan baronang merupakan hama dalam kegiatan budidaya rumput laut.

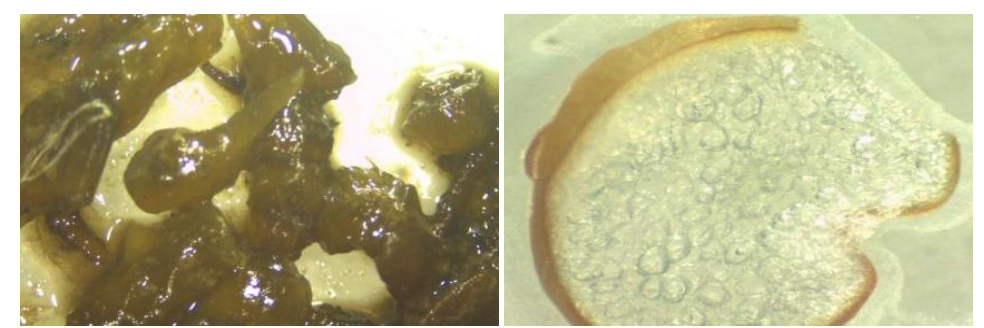

(a)

(b)

Gambar 4. (a) Isi lambung ikan baronang (b) preparat bandingan rumput laut 
Ikan baronang (S. guttatus) memakan rumput laut $K$. Alvarezii dengan cara memotong ujung-ujung thallus serta mencabik bagian tengah atau batang thallus yang ukurannyan lebih besar dari ujung thallus, sehingga banyak dari bagian tersebut ditemukan dalam kondisi tanpa kulit. Hal tersebut didukung oleh pernyataan Faisal et al., (2013) yang menyatakan bahwa ikan baronang memiliki gigi yang kecil hingga hanya dapat menggigit ujung thallus sementara bagian tengah atau batang rumput laut hanya tercabik atau terkelupas tanpa kulit.

4. Hubungan antara padat tebar rumput laut $K$. Alvarezii terhadap grazing ikan baronang

Berdasarkan hasil analisis dengan menggunakan anova nilai sig. $=0,843$ yang artinya tidak ada perbedaan yang nyata antara padat tebar rumput laut $K$. Alvarezii terhadap grazing ikan baronang (S. guttatus). Hal ini berkaitan dengan kemampuan ikan dalam mengonsumsi sejumlah makanan dalam kurun waktu tertentu tidak dipengaruhi oleh banyaknya jumlah makanan yang ada. Hal ini sejalan dengan pernyataan Effendi (1997) menyatakan bahwa tingkat kesukaan ikan terhadap makanan sangat relatif. Karena belum tentu melimpahnya suatu pakan alami dalam suatu perairan dapat dimanfaatkan oleh ikan dikarenakan beberapa faktor yaitu penyebaran organisme sebagai makanan ikan, ketersediaan makanan, pilihan dari ikan, serta faktorfaktor fisik yang mempengaruhi perairan.

5. Hubungan antara grazing ikan baronang terhadap pertumbuhan ikan baronang

Berdasarkan hasil analisis korelasi pearson untuk melihat hubungan antara grazing ikan baronang terhadap pertumbuhan rumput laut diperoleh koefisien korelasi sebesar -0,234 dengan signifikansi sebesar 0,065 $(\mathrm{p}<0,05)$ yang bermakna ketika terjadi peningkatan aktifitas grazing pada rumput laut maka akan menyebabkan penurunan pertumbuhan rumput laut. Hal ini didukung oleh hasil penelitian Ganesan et al.,( 2006) yang menyatakan bahwa produksi rumput laut $K$. Alvarezii menurun $10 \%$ akibat serangan ikan herbivora. Hasil penelitian Kasim dan Mustafa (2007) menyatakan bahwa akibat serangan ikan baronang telah menyebabkan kerusakan pada rumput laut K. Alvarezii sebesar $40 \%$. Ganesan et al., adanya aktifiktas grazing oleh ikan herbivora menjadi salah satu pemicu munculnya penyakit ice-ice yang dapat menurunkan produksi rumput laut sebesar 60\%. Selanjutnya Framegari et al., (2012) memaparkan bahwa pada salinitas tertentu ikan baronang memiliki tingkat konsumsi yang tinggi terhadap rumput laut jenis $K$. alvarezii. Selain itu, pada hasil penelitian lainnya Selviani et al., (2018) melaporkan bahwa ikan baronang lebih banyak mengkonsumsi alga seperti halnya rumput laut.
Adanya aktifitas grazing ikan baronang yang berlangsung secara berkala akan mempengaruhi pertumbuhan rumput laut. Ikan Baronang akan memangsa thallus rumput laut sehingga menyebabkan thallus rumput laut menjadi lembek, rusak dan terhambat pertumbuhannya. Hal tersebut didukung oleh pernyataan Faisal (2013) yang menyatakan bahwa ikan baronang memiliki gigi yang kecil hingga hanya dapat menggigit ujung thallus sementara bagian tengah atau batang rumput laut hanya tercabik atau terkelupas tanpa kulit. Dan didukung pula oleh pernyataan Kasim and Mustafa (2017) menyebutkan bahwa rumput laut lebih disukai oleh Siganus sp. sebagai makanan utama bila dibandingkan dengan tumbuhan makrofita lainnya seperti lamun.

\section{Kesimpulan}

Pertumbuhan ikan baronang ( $S$. guttatus) dipengaruhi oleh pada tebar rumput laut $K$. Alvarezii, dengan pertumbuhan tertinggi berada pada padat tebar $1200 \mathrm{~g} / \mathrm{m}^{2}$ sedangkan yang terendah pada padat tebar $600 \mathrm{~g} / \mathrm{m}^{2}$. Padat tebar rumput laut $K$. Alvarezii tidak berpengaruh terhadap grazing dan pertumbuhan ikan baronang ( $S$. guttatus). Pertumbuhan rumput laut $K$. Alvarezii tidak dipengaruhi oleh pertumbuhan ikan baronang ( $S$. guttatus). Grazing ikan baronang ( $S$. guttatus) dan pertumbuhan rumput laut $K$. Alvarezii berkorelasi negatif. Grazing ikan baronang (S. guttatus) dan pertumbuhan ikan baronang ( $S$. guttatus) berkorelasi positif.

\section{Ucapan Terima Kasih}

Penulis mengucapkan terima kasih kepada Laboratorium Forensik Fakultas Matematika dan Ilmu Pengetahuan Alam (MIPA) Universitas Halu Oleo. Terima kasih juga disampaikan kepada seluruh pihak yang telah memberikan bantuan, saran serta fasilitas dalam penyusunan artikel ini.

\section{Daftar Pustaka}

Ahmed, N. \& Taparhudee, W. (2005). Seaweed Cultivation in Bangladesh: Problems and Potentials. Kasetsart University Fisheries Research Bulletin. 28: 13-21.

Anggadiredja, T.J., Achmad, E., Purwanto, H. \& Sri, I. (2006). Rumput Laut Pembudidayaan, Pengolahan dan Pemasaran Komoditas Perikanan. Penebar Swadaya, Jakarta. 274 hal

Ask E. I. \& Azanza R. V. (2002). Advances in cultivation technology of commercial eucheumatoid species: a review with suggestions for future research. Aquaculture. 206:257-277. 
Athithan, S. (2014). Growth performance of a seaweed, Kappaphycus alvarezii under lined earthen pond condition in Tharuvaikulam of Thoothukudi coast, South East of India. Research Journal of animal, Veterinary and Fishery Science. 2(1): 6-10.

Effendie, M. I. (1979). Metoda Biologi Perikanan. Yayasan Dewi Sri, Bogor. 112 hlm.

Eklof, J.S., Maricela, T.C., Camilla, N. \& Patrick, R. (2006). How do seaweed farms influence local fishery catches in a seagrass-dominated setting in Chwaka Bay, Zanzibar. Department of systems ecology stockholm University, Aquatic Living Resources Journal. 19 : 137 -147.

Faisal, L., Patadjai, R.S. \& Yusnaini (2013). Pertumbuhan Rumput Laut (Kappaphcus alvarezii) dan Ikan Beronang (Siganus guttatus) yang Dibudidayakan Bersama di Keramba Tancap. Jurnal Mina Laut Indonesia, (1) 1: $104-111$.

Feng, G., Zhang. L. Z.P., Liu, J., Zhao, F., Zhang, T. \& Huang, X. R. (2008). Feeding Habit and growth characterictics of Siganus canaliculatus cultured in sea net cage. East China Sea Fisheries Research Journal, $1: 2-8$.

Framegari, V., Nirwani. \& Santosa, G.W. (2012). Studi Herbivori rumput laut Kappaphycus alvarezii (Doty) Doty oleh Ikan Baronang Siganus sp. pada Salinitas yang berbeda. Jurnal Ilmu Kelautan. Universitas Diponegoro, 1:18-27.

Ganesan, M., Thiruppathi, S., Sahu, N., Rengarajan, N., Veer-agurunathan, V. \& Jha, B. (2006). In situ observations on preferential grazing of seaweeds by some herbivores. Curr. Sci. 91, 1256-1260.

Indriani, H. \& Suminarsih, E. (2003). Budidaya, Pengolahan dan Pemasaran Rumput Laut. Penebar Swadaya. Jakarta. 99 Hal.

Kasim, M. \& Asnani (2012). Penetuan musim reproduksi generative dan preferensi perekatan spora rumput laut Eucheuma cottoni. Ilmu Kelautan, 17(4): 209216.

Kasim, M. \& Mustafa A. (2017). Comparison growth of Kappaphycus alvarezii(Rhodophyta, Solieriaceae) Cultivation In Floating Cage And Longline In Indonesia. Aquaculture Reports 6 (2017): 49-55.

Kavale, M. G., Sreenadhan, N. \& Singh, V. V. (2016). Cultivation of Kappaphycus alvarezii (Doty) ex
P.C. Silva along the coast of Palshet, Guhagar, Maharashtra. Indian Journal of Geography and Marine Science. 45(5): 666-670.

Mayunar (2005). Beberapa Aspek Biologi Ikan Baronang Siganus Canaliculatus. OSEANA. 17 (4): 177193.

Merta, L. G . S. (1982). Studi Ekonomi Ikan Baronang Siganus canaliculatus (Park, 1979) di Perairan Teluk Banten, Pantai Utara Jawa Barat. Tesis. Program Pasca Sarjana. Institut Pertanian Bogor. Bogor

Mubarak, H., Ilyas, S., Ismail, W., Wahyuni, I.S., Hartati, S.H., Pratiwi, E., Jangkaru, Z. \& Arifudin, R. (1990). Petunjuk teknis budidaya rumput laut. Pusat Penelitian da Pengembangan Perikanan. Jakarta. 93 hal.

Nontji, A. (2002). Laut Nusantara. Cetakan Ketiga. Penerbit Djambatan, Jakarta.

Ohno, M. (2004). Development of the seaweed cultivation and industry in Japan. Abstracts, $7^{\text {th }}$. Asian Fisheries Forum 2004, 226 pp.

Pillans, R. D., Franklin, C.E. \& Tibbets, I. R. (2004). Food choice in Siganus fiscescens: Influence of Makrophyte Nutrient Content and Availability. Journal of Biology Fish University of Queensland, Australian. 64 : 297 - 309.

Selviani, S., Andriani, I. \& Soekendarsi, E. (2018). Studi Kebiasaan Makanan Ikan Beronang Lingkis Siganus canaliculatus di Kepulauan Tanakeke Takalar Sulawesi Selatan, Jurnal Biologi Makassar (3) $1: 19-25$.

Syafruddin (2008). Zona potensial penangkapan ikan baronang lingkis (Siganus canaliculatus) berdasarkan parameter oseanografi di Perairan Tanakeke Kabupaten Takalar. Torani. 18(4): 325335 . 